\title{
Weathering processes in waste materials from a mining area in a semiarid zone
}

\author{
Cortes Navarro-Hervás ${ }^{a}$, Carmen Pérez-Sirvent ${ }^{\mathrm{a}, \Uparrow}$, María José Martínez-Sánchez $^{\mathrm{a}}$, \\ Mari Luz García-Lorenzo ${ }^{b}$, José Molina ${ }^{c}$ \\ a Department of Agricultural Chemistry, Geology and Pedology, Faculty of Chemistry, University of Murcia, Regional Campus of International Excellence "Campus Mare Nostrum", \\ Campus de Espinardo, 30100 Murcia, Spain \\ ${ }^{\mathrm{b}}$ Department of Petrology and Geochemistry, Faculty of Geology, Complutense University of Madrid, Spain \\ ${ }^{\mathrm{c}}$ Department of Geography, University of Murcia, Murcia, Spain
}

\begin{abstract}
ABSCTRACT
Chemical and mineralogical characterization of waste materials present in an abandoned $\mathrm{Pb}, \mathrm{Zn}-\mathrm{Ag}$ min- ing site (SE, Spain) was carried out. In unaltered rocks, the mineralogy is characterized by plagioclase, pyroxene, magnetite, ilmenite, amphibole, biotite and quartz. Trace-element contents of these samples represent unaltered values. In mine-waste materials, $\mathrm{pH}$ ranged from acidic to slightly acidic and trace-element content was generally high, especially for $\mathrm{Pb}$ and $\mathrm{Zn}$, although there were also substantial As concentrations. X-ray diffraction results suggested that these samples have a complex mineralogy, including alteration products. Surficial materials in the study area were affected by weathering processes, generating supergene assemblages, including $\mathrm{Fe}$ and $\mathrm{Mn}$ oxides and hydroxides, carbonates, hydrated sulfates and jarosite. Knowledge of the geochemical processes that took place in the past and which are still taking place provide an important tool for assessing associated environmental problems in this area.
\end{abstract}

\section{Introduction}

The nature of materials present at mine sites is a consequence of the circumstances that have prevailed at the site and have affected alteration processes. Open pit mining activities have a serious environmental impact on soils and streams, as a result of having generated millions of tons of sulfide-rich tailings and waste material (Piatak et al., 2004; Bhattacharya et al., 2006; Rodríguez et al., 2009).

Modern mineral extraction and treatment processes are very efficient and resulting wastes contain lower concentrations of trace elements than their historical counterparts. However, less efficient separation processes mean that wastes from historical mining operations may contain higher trace element concentrations (Lottermoser, 2007).

There are several mine sites in southeastern Spain, such as the Sierra Minera of Cartagena-La Unión (Murcia). These deposits have been exploited since ancient times, although activity was much more intensive in the 50 a preceding the $1980 \mathrm{~s}$, when economic conditions halted activity. Up to 1991 Sierra Minera, produced large quantities of $\mathrm{Pb}, \mathrm{Ag}, \mathrm{Zn}$ and pyrite. Materials present in this area are a heterogeneous mixture of rock fragments, waste rock, sub-economic mineralized rock and tailing materials. These materials are experiencing ongoing weathering processes.

\footnotetext{
$\Uparrow$ Corresponding author. Tel.: +34 868 887449; fax: +34 868884148 . E-mail address: melita@um.es (C. Pérez-Sirvent).
}

Given the complexity of the materials and the importance of establishing some pattern in their behavior during alteration and weathering, the aim of this work was to study the chemical and mineralogical composition of unaltered and altered rocks. In addition, the trace-element content was measured and comparisons made between host rocks and altered rocks.

\section{Study area}

\subsection{Location}

Sierra Minera of Cartagena-La Unión is located in the SE part of the Murcia Region (Spain). It is a coastal mountain range with an approximate extent of $50 \mathrm{~km}$ and bound by the Mediterranean Sea in the south and by the Campo de Cartagena in the north. The study area was one of the main mining districts in southeastern Spain (Martínez-Sánchez et al., 2008). As a result of mining, the study area has a significant number of contaminant sources resulting from mining spoil, waste piles and foundry residues. The extractive activity has produced morphological changes, including modification of the drainage network with changes of natural slopes that promote erosion processes, which are exacerbated by the scarce vegetation present in the area (Fig. 1).

The study area, Cabezo Rajao, is located in the Sierra Minera, and has an area of approximately 270 ha. The morphology of the whole area consists mainly of a predominantly flat topography with slopes of less than $10 \%$. Cabezo Rajao is an elevated promontory in the 


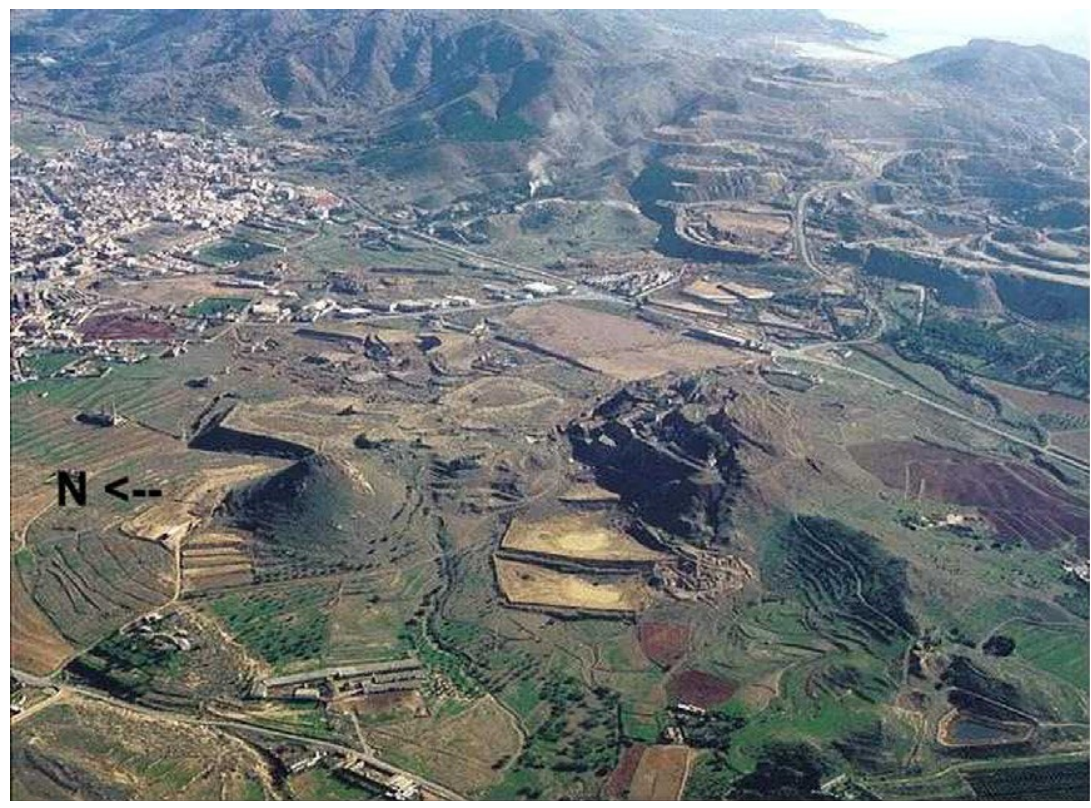

Fig. 1. Aerial view of the study area and surroundings.

center of the zone with a maximum height of $198 \mathrm{~m}$, with slopes greater than $15 \%$ that increase to $30 \%$ towards the top.

The average annual temperature is $17^{\circ} \mathrm{C}$, and the annual precipitation does not exceed $300 \mathrm{~mm}$, with occasional torrential rainfalls, which occur between the end of summer and autumn. Perennial streams are absent, and surface water consists of ephemeral streams, which only flow during rainfall events. Stream flow is flashy and a significant amount of sediment is transported after long-lasting rainfall. Surface water drains to the Mar Menor lagoon, a nearby area of exceptional environmental interest which is protected by several designations, such as being a Site of Community Interest (pSCI), a Zone of Special Protection of Birds (SPBs), a wetland RAMSAR and a Special Protected Zone of Importance for the Mediterranean.

Mines have been exploited since antiquity (Phoenician, Carthagenian and Roman remains have been found) although more intensively in the 50 a preceding the $1980 \mathrm{~s}$, after which a crisis in the siderometallurgic sector put an end to such activity (Navarro et al., 2008).

The hot, arid climatic conditions with occasional torrential rainfall mean that erosion phenomena and the transportation of particulate material lead to the dispersion of the contaminant metals. Transformation of the metals from their original sulfide form through oxidation over a long period of time has culminated in acidic residues, the dissolution of the metals and their redistribution in various chemical forms among the solid and aqueous phases (Navarro et al., 2006).

\subsection{Geological setting}

Sierra Minera was one of the main mining districts of southeastern Spain, where stratabound sulfide deposits are found in carbonate sequences in the Nevado-Filabride and Alpujarride complexes (Robles-Arenas et al., 2006). They consist of a series of superimposed thrust sheets of Alpine age, subsequently affected by metamorphism. After significant erosion, a transgressive sequence of sediments was deposited. After the Neogene, there was a phase of brittle deformation followed by volcanism, uplift of the Sierra Minera and additional erosion.
This $\mathrm{Pb}-\mathrm{Zn}-(\mathrm{Ag}-\mathrm{Sn})$ district is an excellent example of the relationship between basin formation, normal faulting, volcanism, hydrothermal activity and mineral deposition (Manteca and Ovejero, 1992). The combination of all these processes creates an exceptional concentration of metals. Neogene magmatism is represented by calc-alkaline rocks (andesites, pyroxene and amphibolebearing andesites and dacites) and alkali basalts (basanites and olivine basalts). Despite their young age, the erupted materials are highly weathered and the volcanic vents are strongly eroded (López Ruíz et al., 2002). When these volcanic rocks push up, they constitute the typical "cabezos" of the area, the Mar Menor islands (a marine lagoon aligned along $70^{\circ} \mathrm{N}$ ), and embankments and domes (aligned $130^{\circ} \mathrm{N}$ ), intersecting the litho-structural horizons including the Miocene. These volcanic rocks, dacites and andesites have been affected by strong hydrothermal alteration in areas where mineral deposits occur. The strong hydrothermal alteration observed in the rocks is responsible for the minerals that have formed and which can be observed in a network of fractures. The processes affect both the volcanic rock and the basement. The primary mineralization of the area was followed by strong secondary weathering processes, resulting in the appearance of a large number of secondary minerals, where these processes affected both the primary mineralization products and the host rocks.

From a mineralogical point of view, the study area is a good example of submarine base-metal mineralization and hydrothermal alteration associated with the intrusion of volcanic rock of intermediate composition (potassic andesites and dacites) (Manteca and Ovejero, 1992). The volcanogenic massive sulfide (VMS) deposit is composed of pyrite, sphalerite, galena, marcasite and, locally, pyrrhotite as principal sulfides, whereas chalcopyrite, arsenopyrite, tetrahedrite and stannite occurs as accessories. The main carbonate mineral is the siderite; some varieties contain $\mathrm{Zn}$ and $\mathrm{Mn}$.

The deposit has a very extensive paragenesis of polymetalllic sulfides and gossan minerals (Ag- $\mathrm{Pb}-\mathrm{Zn}-\mathrm{Fe}-\mathrm{Mn}-\mathrm{Sn}$ and other metals) such as anglesite, cerussite, galena, sphalerite, pyrolusite, pyrrhotite, marcasite, ludlamite, vivianite, barite, calcite, gypsum, amethyst quartz and chalcedony. The simple sulfide mineral assemblages of these deposits consist of galena, sphalerite, pyrite, marcasite and chalcopyrite, together with trace amounts of other 
sulfides and sulfosalt minerals. Secondary minerals consist of smithsonite, hemimorphite, anglesite, cerussite, celestite, malachite, sulfur, goslarite, epsomite, gypsum, melanterite, szomolnokite, copiapite, carphosiderite, diadochite, hydrous $\mathrm{Fe}$ oxide minerals, hematite and greenockite.

\section{Materials and methods}

Materials selected for this work represent a heterogeneous mixture of unaltered rock fragments and selected mine wastes. These materials, from diverse origins, are undergoing weathering, but reaction mechanisms and resulting products are not the same because the physico-chemical properties of the materials are different. The mine waste samples were characterized chemically and mineralogically and then to describe the alteration process.

\subsection{Unaltered/host rocks}

Five volcanic rocks were selected for this study, representing different types of parent materials found in the study area (Fig. 2). Samples were taken near the mineralized zone, in units showing no evidence of alteration. The volcanic rocks in the study area are calc-alkaline, represented by potassic andesites and dacites (López Ruíz et al., 2002), characterized by fine grained porphyritic textures with phenocrysts of plagioclase, hornblende, biotite and augite.

\subsection{Mine waste}

Materials found in the study area are the result of the mixing and sedimentation of residues from ore processing. These materials include unaltered rock, weathered rock, primary mineralization products (metallic sulfides), secondary mineralization products (hydrothermal alteration products and products from the weathering of sulfides) and residues from the mechanical and metallurgical treatment of ores (mineral panning, mineral processing and mineral washing).

A total of eighteen samples, representative of the different soils or waste materials were collected (Fig. 2). Sampling sites SH1-SH9 are located on mine-waste tips; sampling sites T1-T5 correspond to tailings and samples $\mathrm{S} 1-\mathrm{S} 4$ stream sediments.

Sampling sites SH1-SH4 were located in the highest part of the study area, and, therefore, were unaffected by sedimentation processes. However, this zone still shows the effects of mining operations because it contains mine shafts and air vents. In addition, substantial quantities of the spoils were initially deposited here. The SH5-SH7 sampling points are representative of coarse materials, mostly located on steep slopes where the effect of erosion is evident. The oldest waste piles (T2), dating back to the 6th Century B.C., have the finest sediments. Sample SH8 corresponds to a gently sloping area whereas SH9 is located in a zone characterized by the presence of waste heaps. T1 is located in the lowest topographic position, where waste piles have been constructed. The T3-T5 sampling points correspond to an area recovered from old waste piles and finally, the S1-S4 sampling points are representative of gully water courses.

\subsection{Sample preparation and analysis}

All the samples (sediments and mine wastes) were air dried and sieved to $<2 \mathrm{~mm}$ prior to analysis. The $\mathrm{pH}$ was measured in a 1:5 suspension of soil in Milli-Q water; electrical conductivity (EC) $\left(\mathrm{dS} \mathrm{m} \mathrm{m}^{-1}\right.$ at $25^{\circ} \mathrm{C}$ ) was measured in the extracts obtained by filtering the $1: 5$ suspensions through a $0.45 \mathrm{~lm}$ cellulose acetate disk filter.

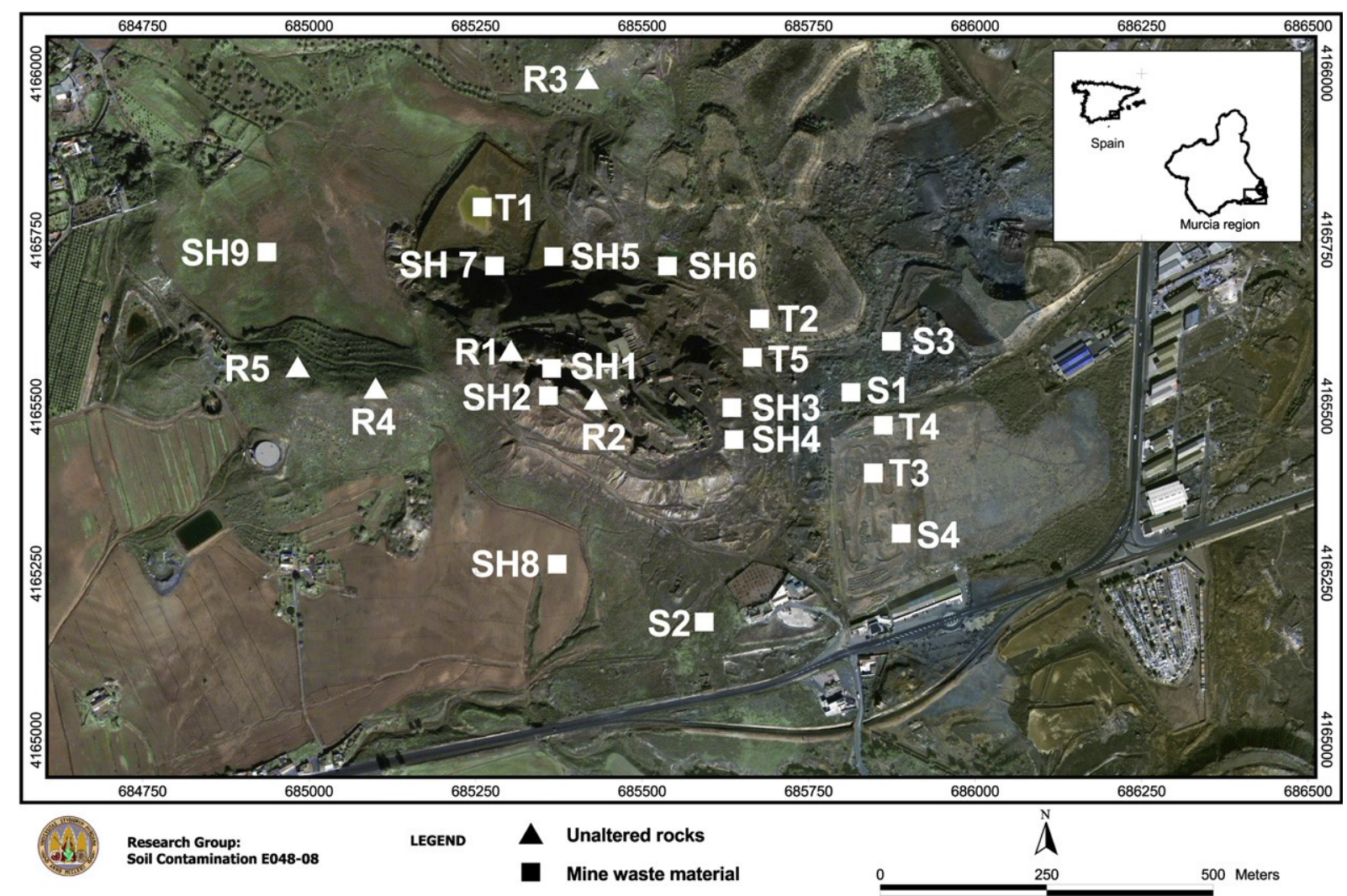

Fig. 2. Sampling sites in the study area. 
In addition, equivalent $\mathrm{CaCO}_{3}(\%)$ was determined by the volumetric method using a Bernard calcimeter. Textural analysis was performed after dispersion of the fine soil combined with extraction using a Robinson pipette and sieving.

The major elements were determined by X-ray Fluorescence Spectrometry (XRF) using a Philips MAGIXPro XRF Spectrometer and the semiquantitative IQ+ program. The spectrometer was calibrated using standard reference materials (NIST SRM 2711 Montana Soil, NIST SRM 2709 San Joaquin Soil, NCS DC 73319, NCS DC 73320, NCS DC 73321, NCS DC 73323, NCS DC 73324, NCS DC 73325, NRC BCSS-1, NRC PACS-1).

Pellets for XRF were made by adding boric acid to the sample in an $\mathrm{Al}$ capsule and compacting it in a Herzog press at a pressure of $200 \mathrm{kN}$. This technique has been successfully applied to the semiquantitative and quantitative determination of the principal components of soils (Amonette and Sanders, 1994; Ure, 1995), although it is less suitable for determining minor components.

A semiquantitative estimation of the mineralogical composition of the samples was made by powder X-ray diffraction (XRD) analysis using $\mathrm{Cu}$ Ka radiation with a PW3040 Philips Diffractometer. Software was used to analyze diffractograms. The powder diffraction database PDF2 was used for peak identification, but it is not accurate for phases below $2 \mathrm{wt} . \%$ in a sample (depending on the crystallinity of individual minerals).

The mass loss caused by heating was studied at temperatures ranging from 25 to $1000{ }^{\circ} \mathrm{C}$ using a Mettler TA 3000 thermogravimetric instrument.

To determine trace-element content, sediments were first ground to a fine powder using a $\mathrm{Zr}$ ball mill. Sediment samples, $0.1 \mathrm{~g}$, were placed in Teflon vessels and $5 \mathrm{~mL}$ of concentrated $\mathrm{HF}$, $200 \mathrm{lL}$ of concentrated $\mathrm{HNO}_{3}$ and $5 \mathrm{~mL}$ of water were added. When digestion was complete ( $15 \mathrm{~min}$ at $1000 \mathrm{~W}$ in a Milestone ETHOS PLUS microwave oven), the samples were transferred to a volumetric flask and brought to $50 \mathrm{~mL}$. The $\mathrm{Zn}, \mathrm{Mn}$ and Fe contents were determined by flame atomic absorption spectrometry (FAAS) using a Perkin-Elmer 1100B Spectrophotometer. The $\mathrm{Pb}, \mathrm{Cd}$ and $\mathrm{Cu}$ contents were determined by electrothermal atomization atomic absorption spectrometry (ETAAS) using an Unicam 929 AAS spectrometer. The As content was measured by atomic fluorescence spectrometry using an automated continuous flow hydride generation spectrometer (PSA Millenium Merlin 10055 for As). The reliability of the results was verified by analyzing standard reference materials, blanks and replicate samples. The results showed a RSD close to $5 \%$ and agreed with the certified values. All reagents were of analytical grade or Suprapur quality. Stock standard solutions were Merck Certificate AA standards. Milli-Q quality water was used in all the experiments. The plastic and glassware were cleaned by soaking in a $14 \%(\mathrm{v} / \mathrm{v}) \mathrm{HNO}_{3}$ solution for $24 \mathrm{~h}$ and then rinsing with water.

\subsection{Statistical analysis}

The Statgraphics Centurion software v.16 was used for multivariate analysis, including correlation matrices, principal component and factor analysis. The data were initially transformed using the CLR (centered log-transformation) (Pawlowsky-Glahn and Egozcuel, 2006). Pearson's product moment correlation coefficients were used to produce a correlation matrix and then to identify possible relationships between trace element content and soil properties.

Factorial analysis permits a statistical approximation for analyzing interrelationships among a large number of variables. Factorial analysis was carried out by the principal components extraction method and varimax normalized rotation of the factors. Varimax rotation ensures that each variable is maximally correlated with only one principal component while having a near-zero association with the other components.

\section{Results and discussion}

\subsection{Unaltered rocks}

X-ray fluorescence analysis of the unaltered rocks (Table 1) showed a homogeneous content of more than $54 \%$ of $\mathrm{SiO}_{2}$ in all the samples (mean 58\%). The $\mathrm{Al}_{2} \mathrm{O}_{3}$ content was also homogeneous in all samples with a mean value of $17 \%$. On the other hand, $\mathrm{Fe}_{2} \mathrm{O}_{3}$, $\mathrm{MgO}$ and $\mathrm{K}_{2} \mathrm{O}$ contents varied as a function of the mineralogical composition. Fig. 3 shows the distribution of the principal elements in the selected rocks, compared with the mean characteristics of calc-alkaline type rocks, potassic dacites and andesites (Rösler and Lange, 1972). The mineralogical composition of the typical calc-alkaline volcanic rocks in the study area is characterized by plagioclase, pyroxene, magnetite, ilmenite, amphibole, biotite and quartz (López Ruíz et al., 2002). X-ray diffraction analysis of the host rocks did not identify any hydrothermal alteration (sulfides and kaolinite) or weathering (alunite, jarosite and gypsum) products. The mineralogy of the samples allows the establishment

Table 1

Chemical and mineralogical composition (wt.\%) of unaltered rocks.

\begin{tabular}{|c|c|c|c|c|c|c|c|c|c|}
\hline$\%$ & $\mathrm{R} 1$ & $\mathrm{R} 2$ & $\mathrm{R} 3$ & $\mathrm{R} 4$ & R5 & Maximum & Minimum & Mean & Standard deviation \\
\hline $\mathrm{Na}_{2} \mathrm{O}$ & 0.03 & 0.08 & 0.12 & 0.28 & 0.22 & 0.28 & 0.03 & 0.15 & 0.10 \\
\hline $\mathrm{MgO}$ & 6.56 & 2.20 & 0.48 & 5.13 & 3.68 & 6.56 & 0.48 & 3.61 & 2.39 \\
\hline $\mathrm{Al}_{2} \mathrm{O}_{3}$ & 17.54 & 16.21 & 21.16 & 14.29 & 16.22 & 21.16 & 14.29 & 17.08 & 2.56 \\
\hline $\mathrm{SiO}_{2}$ & 57.20 & 54.86 & 63.84 & 56.37 & 58.30 & 63.84 & 54.86 & 58.11 & 3.44 \\
\hline $\mathrm{P}_{2} \mathrm{O}_{5}$ & 0.54 & 0.40 & 0.30 & 1.19 & 0.90 & 1.19 & 0.30 & 0.67 & 0.37 \\
\hline $\mathrm{SO}_{3}$ & 0.41 & 0.52 & 0.30 & 0.26 & 0.13 & 0.52 & 0.13 & 0.32 & 0.15 \\
\hline $\mathrm{K}_{2} \mathrm{O}$ & 1.92 & 1.85 & 5.07 & 5.54 & 5.73 & 5.73 & 1.85 & 4.02 & 1.97 \\
\hline $\mathrm{CaO}$ & 0.68 & 0.44 & 0.11 & 2.77 & 1.19 & 2.77 & 0.11 & 1.04 & 1.05 \\
\hline $\mathrm{TiO}_{2}$ & 0.68 & 0.50 & 0.50 & 0.96 & 0.88 & 0.96 & 0.50 & 0.70 & 0.21 \\
\hline $\mathrm{MnO}_{2}$ & 0.25 & 0.12 & - & 0.33 & 0.20 & 0.33 & 0.00 & 0.18 & 0.13 \\
\hline $\mathrm{Fe}_{2} \mathrm{O}_{3}$ & 12.29 & 15.78 & 2.13 & 5.85 & 7.32 & 15.78 & 2.13 & 8.67 & 5.39 \\
\hline $\mathrm{ZnO}$ & 0.20 & 0.20 & 0.04 & 0.13 & 0.25 & 0.25 & 0.04 & 0.16 & 0.08 \\
\hline $\mathrm{PbO}$ & 0.04 & 0.05 & 0.12 & 0.02 & 0.02 & 0.12 & 0.02 & 0.05 & 0.04 \\
\hline LOI & 1.48 & 6.69 & 5.61 & 6.27 & 4.51 & 6.69 & 1.48 & 4.91 & 2.09 \\
\hline Clay minerals & 05 & 63 & 11 & 54 & 46 & & & & \\
\hline Feldspars & - & - & 22 & 21 & 24 & & & & \\
\hline Quartz & 45 & 37 & 67 & 19 & 30 & & & & \\
\hline Calcite & - & - & - & 3 & - & & & & \\
\hline Amphibole & 5 & - & - & 3 & - & & & & \\
\hline
\end{tabular}



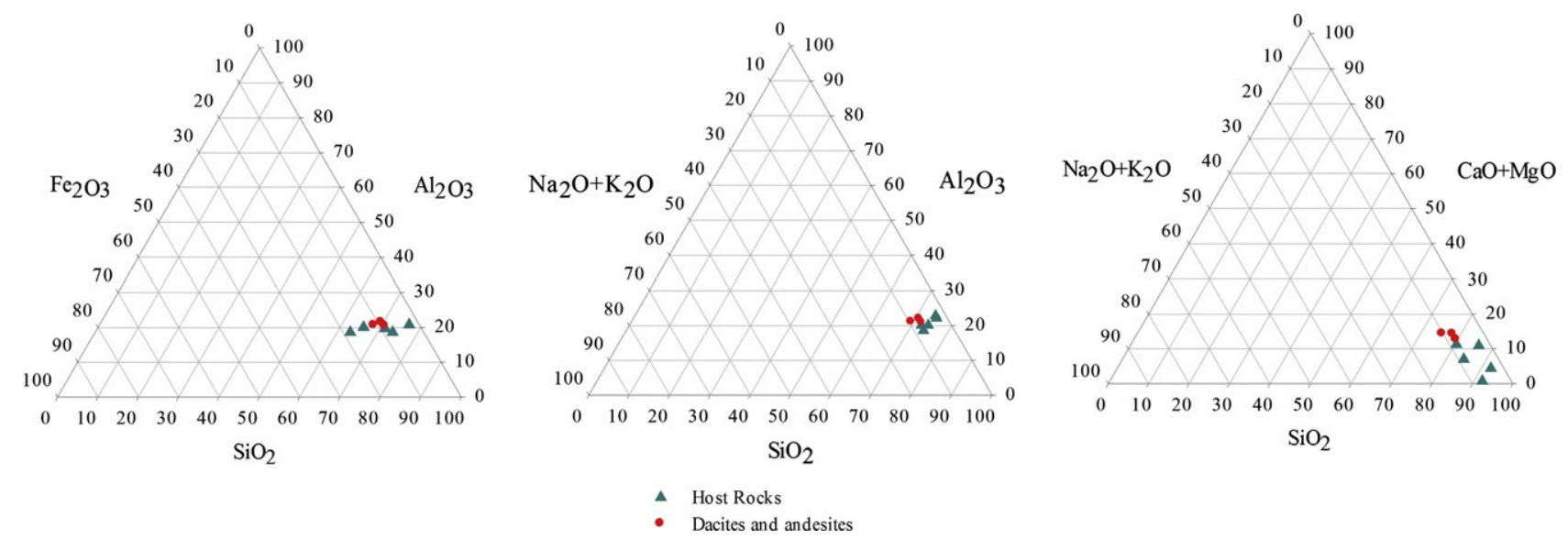

Fig. 3. Distribution of major elements in selected rocks and in calc-alkaline type rocks, potassic dacites and andesites (wt.\%).

Table 2

General analytical determinations and total trace element content of mine waste samples.

\begin{tabular}{|c|c|c|c|c|c|c|c|c|c|c|}
\hline & $\mathrm{pH}$ & $\mathrm{CaCO}_{3}$ (wt.\%) & Clay (wt.\%) & Silt (wt.\%) & Sand (wt.\%) & $\mathrm{Pb}\left(\mathrm{mg} \mathrm{kg}^{-1}\right)$ & $\mathrm{Cd}\left(\mathrm{mg} \mathrm{kg}^{-1}\right)$ & $\mathrm{Zn}\left(\mathrm{mg} \mathrm{kg}^{-1}\right)$ & $\mathrm{Cu}\left(\mathrm{mg} \mathrm{kg}^{-1}\right)$ & As $\left(\mathrm{mg} \mathrm{kg}^{-1}\right)$ \\
\hline SH1 & 3.2 & $<\mathrm{dl}$ & 6.2 & 45.6 & 48.2 & 8770 & 9 & 3190 & 168 & 520 \\
\hline SH2 & 3.77 & $<\mathrm{dl}$ & 3.6 & 59.6 & 36.8 & 19,206 & 8 & 4772 & 625 & 587 \\
\hline SH3 & 4.81 & $<\mathrm{dl}$ & 2.3 & 29.3 & 68.4 & 5718 & 18 & 8205 & 170 & 135 \\
\hline $\mathrm{SH} 4$ & 3.13 & $<\mathrm{dl}$ & 6.9 & 37.8 & 55.4 & 15,608 & 104 & 46,365 & 351 & 271 \\
\hline SH5 & 5.69 & 1.3 & 6.4 & 71 & 22.6 & 11,137 & 17 & 8029 & 288 & 438 \\
\hline SH6 & 4.9 & 0.7 & 10.6 & 19.1 & 70.3 & 6066 & 10 & 6007 & 193 & 251 \\
\hline SH7 & 8.24 & 11.3 & 10 & 57.4 & 32.6 & 228 & 15 & 3590 & 36 & 103 \\
\hline SH8 & 7.97 & $<\mathrm{dl}$ & 28 & 17.2 & 54.8 & 2044 & 2 & 1241 & 44 & 67 \\
\hline SH9 & 6.17 & $<\mathrm{dl}$ & 6.4 & 24 & 69.6 & 16,764 & 19 & 13,999 & 2255 & 205 \\
\hline $\mathrm{T} 1$ & 4.55 & $<\mathrm{dl}$ & 6.6 & 8.9 & 84.5 & 2737 & 7 & 3351 & 93 & 215 \\
\hline $\mathrm{T} 2$ & 3.79 & $<\mathrm{dl}$ & 10.8 & 22.5 & 66.7 & 3867 & 10 & 3385 & 80 & 453 \\
\hline T3 & 8.35 & 11.4 & 4.8 & 59.2 & 36 & 1160 & 18 & 7823 & 69 & 393 \\
\hline $\mathrm{T} 4$ & 4.01 & $<\mathrm{dl}$ & 25.3 & 46.2 & 28.5 & 16,957 & 322 & 53,125 & 702 & 460 \\
\hline $\mathrm{T} 5$ & 3.53 & $<\mathrm{dl}$ & 8.8 & 34.9 & 56.3 & 18,738 & 54 & 7883 & 437 & 455 \\
\hline $\mathrm{S} 1$ & 5.49 & $<\mathrm{dl}$ & 5.2 & 14.2 & 80.6 & 3885 & 22 & 13,250 & 110 & 219 \\
\hline $\mathrm{S} 2$ & 7.18 & $<\mathrm{dl}$ & 7.8 & 24.2 & 68 & 6075 & 68 & 33,724 & 108 & 324 \\
\hline S3 & 4.38 & $<\mathrm{dl}$ & 8.4 & 5.3 & 86.3 & 7787 & 13 & 5756 & 153 & 304 \\
\hline $\mathrm{S} 4$ & 8.27 & 10.0 & 10.7 & 43 & 46.3 & 1840 & 21 & 1839 & 98 & 265 \\
\hline
\end{tabular}

of five groups. All the samples, except R3, contained chlorite-type phyllosilicates, which explained the high $\mathrm{Fe}_{2} \mathrm{O}_{3}$ values found in the chemical analysis. Samples R1 and R2 were mainly composed of mica, chlorite and quartz, with a small amount of amphibole (hornblende). R3 was composed of mica, quartz and feldspars, and R5 showed the same composition plus chlorite. Lastly, R4 showed a higher mica content than R5 and, lower quantities of calcite and hornblende. Calcite, which only appears in one sample, was formed during the last stages of alteration (Ortiz-González, 1991).

Observed anomalies could be due either to single samples that represent a different lithology in the area or, rocks that were not pristine but had undergone postmagmatic alteration of their chemical and mineralogical composition. The scarcity of plagioclase and amphibole and the presence of phyllosilicate minerals indicates that these rocks have undergone chloritization (Manteca and Ovejero, 1992).
The trace-element contents of these samples correspond to their original igneous values. For this reason, even if these rocks were not exclusively the result of volcanic processes, they can be considered representative of the host rock.

\subsection{Mine waste materials}

The mine waste samples included in this study are the result of mixing and sedimentation processes of mine wastes, including products of metallurgical processes and unaltered host rocks together with metallic sulfides and their weathering products. Weathering processes in hypogene mineralization materials have caused intense modifications and secondary minerals have formed. Therefore, studied materials showed great heterogeneity in their textures and chemical and mineralogical compositions. Table 2 summarizes results for the major, minor and trace element geochemistry of the mine-waste samples. The paste $\mathrm{pH}$ of the samples

Table 3

Major elements (wt.\%) of selected mine waste materials.

\begin{tabular}{|c|c|c|c|c|c|c|c|c|c|c|c|c|c|c|}
\hline & $\mathrm{Na}_{2} \mathrm{O}$ & $\mathrm{MgO}$ & $\mathrm{Al}_{2} \mathrm{O}_{3}$ & $\mathrm{SiO}_{2}$ & $\mathrm{P}_{2} \mathrm{O}_{5}$ & $\mathrm{SO}_{3}$ & $\mathrm{~K}_{2} \mathrm{O}$ & $\mathrm{CaO}$ & $\mathrm{TiO}_{2}$ & $\mathrm{MnO}_{2}$ & $\mathrm{Fe}_{2} \mathrm{O}_{3}$ & $\mathrm{ZnO}$ & $\mathrm{PbO}$ & LOI \\
\hline Maximum & 1.79 & 4.64 & 20.47 & 59.07 & 0.44 & 24 & 3.88 & 10.12 & 0.62 & 0.75 & 24.98 & 7.18 & 2.94 & 24.98 \\
\hline Mean & 0.54 & 2.05 & 13.12 & 41.52 & 0.25 & 10.38 & 1.63 & 3.90 & 0.43 & 0.25 & 15.61 & 1.78 & 1.25 & 16.18 \\
\hline Minimum & 0.14 & 0.52 & 3.76 & 11.72 & 0.08 & 0.91 & 0.28 & 1.36 & 0.04 & 0.03 & 7.43 & 0.14 & 0.20 & 7.43 \\
\hline Standard deviation & 0.41 & 1.23 & 4.30 & 11.10 & 0.12 & 5.65 & 0.90 & 2.96 & 0.15 & 0.24 & 4.65 & 1.96 & 0.94 & 4.82 \\
\hline
\end{tabular}



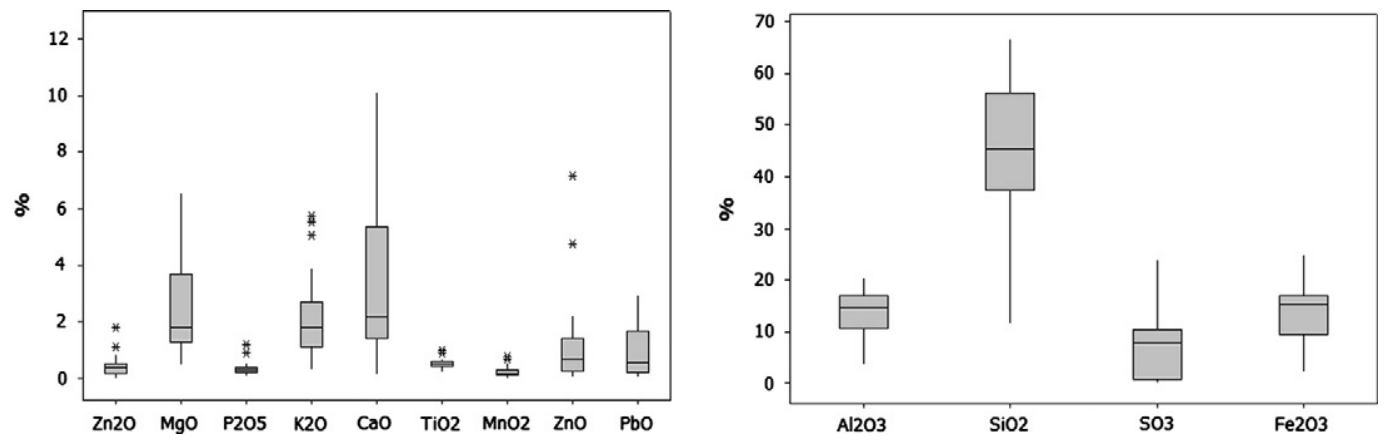

Fig. 4. Box plots of major elements in mine-waste materials (wt.\%).

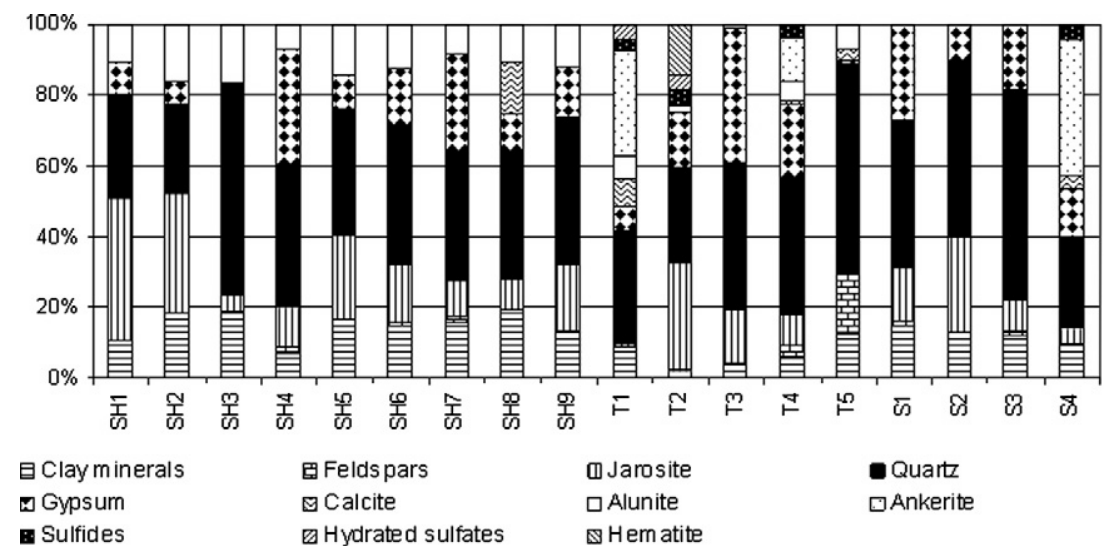

Fig. 5. Mineralogical composition of samples.

ranged from acidic to slightly acidic. The highest $\mathrm{pH}$ values found in sediments were from mine wastes that have been mixed with carbonate-rich surficial materials, such as for $\mathrm{SH} 7$ and those samples located in the flash-flood channels (S2 and $\mathrm{S} 4$ ). The equivalent $\mathrm{CaCO}_{3}$ content was zero in most cases but not for samples that had received contributions from carbonate-rich soils located in the surrounding areas or that have undergone secondary carbonation under natural conditions (e.g., SH7). The texture of the selected materials varied with the topographic setting: samples with finer fractions have undergone in situ weathering processes, whereas

Table 4

Pearson's correlation matrix between major elements and mineralogical composition in mine wastes.

\begin{tabular}{|c|c|c|c|c|c|c|c|c|c|c|c|c|}
\hline & $\mathrm{Na}_{2} \mathrm{O}$ & $\mathrm{MgO}$ & $\mathrm{Al}_{2} \mathrm{O}_{3}$ & $\mathrm{SiO}_{2}$ & $\mathrm{P}_{2} \mathrm{O}_{5}$ & $\mathrm{SO}_{3}$ & $\mathrm{~K}_{2} \mathrm{O}$ & $\mathrm{CaO}$ & $\mathrm{TiO}_{2}$ & $\mathrm{MnO}_{2}$ & $\mathrm{Fe}_{2} \mathrm{O}_{3}$ & LOI \\
\hline $\mathrm{MgO}$ & -0.392 & & 0.049 & 0.165 & 0.372 & -0.383 & 0.249 & $0.545^{*}$ & 0.276 & $0.796^{* *}$ & -0.393 & \\
\hline $\mathrm{Al}_{2} \mathrm{O}_{3}$ & -0.209 & 0.049 & & $0.797^{* *}$ & $0.679^{* * *}$ & $-0.586^{*}$ & $0.733^{* *}$ & -0.450 & $0.898^{* *}$ & -0.270 & $-0.527^{*}$ & \\
\hline $\mathrm{SiO}_{2}$ & -0.336 & 0.165 & 0.796 & & $0.543^{*}$ & $-0.689^{* *}$ & $0.656^{* * *}$ & -0.332 & $0.767^{* * *}$ & -0.108 & $-0.592^{* *}$ & \\
\hline $\mathrm{P}_{2} \mathrm{O}_{5}$ & 0.265 & -0.372 & $0.679^{* *}$ & $0.543^{*}$ & & -0.165 & 0.303 & $-0.659^{* *}$ & $0.490^{*}$ & -0.433 & -0.034 & \\
\hline $\mathrm{SO}_{3}$ & 0.204 & -0.383 & $-0.586^{*}$ & $-0.689^{* *}$ & -0.165 & & $-0.619^{* *}$ & 0.224 & $-0.607^{*}$ & -0.142 & $0.742^{* *}$ & \\
\hline $\mathrm{K}_{2} \mathrm{O}$ & -0.330 & 0.249 & $0.733^{* *}$ & $0.655^{* * *}$ & 0.303 & $-0.619^{* *}$ & & -0.090 & $0.866^{* *}$ & -0.059 & $-0.621^{* *}$ & \\
\hline $\mathrm{CaO}$ & -0.288 & $0.549^{* * *}$ & -0.450 & -0.332 & $-0.658^{* *}$ & 0.224 & -0.090 & & -0.284 & $0.773^{* *}$ & -0.219 & \\
\hline $\mathrm{TiO}_{2}$ & -0.355 & 0.276 & $0.898^{* *}$ & $0.767^{* *}$ & $0.490^{*}$ & $-0.607^{* * *}$ & $0.866^{* *}$ & -0.284 & & -0.155 & $-0.509^{* *}$ & \\
\hline $\mathrm{MnO}_{2}$ & -0.173 & $0.797^{* *}$ & -0.270 & -0.108 & -0.433 & -0.142 & -0.059 & $0.773^{* *}$ & -0.155 & & -0.354 & \\
\hline $\mathrm{Fe}_{2} \mathrm{O}_{3}$ & 0.303 & -0.393 & -0.527 & $-0.592^{\cdots}$ & -0.034 & $0.742^{\cdots}$ & -0.621 & -0.219 & $-0.509^{\prime}$ & -0.354 & & \\
\hline LOI & 0.340 & 0.291 & $-0.703^{*}$ & $-0.800^{* *}$ & -0.245 & $0.688^{*}$ & -0.409 & $0.687^{*}$ & $-0.697^{*}$ & 0.250 & $0.589^{*}$ & \\
\hline Clay & -0.319 & 0.162 & $0.871^{* *}$ & $0.842^{* *}$ & 0.461 & $-0.559^{*}$ & $0.799^{* *}$ & -0.276 & $0.869^{* * *}$ & -0.184 & $-0.547^{*}$ & $-0.554^{*}$ \\
\hline Fsp & -0.039 & 0.455 & 0.140 & 0.333 & -0.061 & -0.394 & 0.188 & 0.359 & 0.147 & $0.545^{*}$ & $-0.532^{*}$ & -0.456 \\
\hline Qtz & 0.159 & 0.003 & 0.140 & $0.486^{*}$ & $0.489^{*}$ & -0.225 & 0.013 & -0.301 & 0.159 & -0.055 & -0.004 & -0.417 \\
\hline $\mathrm{Cal}$ & -0.373 & $0.746^{*}$ & 0.039 & 0.134 & -0.460 & -0.429 & 0.267 & $0.659^{*}$ & 0.151 & $0.768^{* * *}$ & $-0.655^{* *}$ & $-0.495^{*}$ \\
\hline $\mathrm{Sd}$ & $-0.525^{\pi}$ & $0.526^{*}$ & -0.162 & -0.071 & -0.605 & 0.029 & -0.082 & $0.616^{\pi}$ & -0.165 & $0.557^{\pi}$ & -0.209 & -0.146 \\
\hline Ank & -0.356 & $0.532^{*}$ & -0.178 & -0.087 & -0.399 & 0.056 & -0.083 & $0.666^{\pi}$ & -0.157 & $0.699^{\text {*w }}$ & -0.122 & -0.172 \\
\hline Jar & 0.195 & $-0.520^{*}$ & -0.267 & -0.377 & 0.187 & $0.757^{* *}$ & $-0.477^{*}$ & -0.210 & -0.393 & -0.370 & $0.818^{* *}$ & $0.619^{* *}$ \\
\hline Alu & 0.077 & 0.145 & 0.249 & 0.280 & -0.074 & $-0.809^{* * *}$ & 0.380 & -0.193 & 0.239 & 0.017 & $-0.518^{*}$ & -0.301 \\
\hline Gp & -0.225 & 0.289 & 0.224 & 0.103 & 0.080 & 0.044 & 0.235 & $0.549^{\circ}$ & 0.187 & $0.542^{\prime \prime}$ & -0.400 & -0.250 \\
\hline Aka & 0.207 & -0.425 & -0.384 & -0.284 & 0.060 & 0.438 & -0.374 & -0.388 & -0.332 & $-0.501^{\pi}$ & $0.677^{\star \pi}$ & 0.457 \\
\hline H.S & 0.357 & 0.000 & $-0.709^{\pi \pi}$ & $-0.669^{\pi \pi}$ & $-0.582^{\pi}$ & 0.442 & $-0.768^{\pi \pi}$ & 0.263 & $-0.816^{\pi \pi}$ & 0.249 & 0.322 & $0.588^{\circ}$ \\
\hline $\mathrm{S}$ & 0.012 & 0.258 & $-0.665^{* *}$ & $-0.606^{* *}$ & $-0.595^{* *}$ & 0.372 & $-0.639^{* *}$ & $0.582^{*}$ & $-0.703^{* *}$ & $0.612^{*}$ & 0.230 & 0.314 \\
\hline Hem & 0.416 & -0.268 & $-0.730^{* *}$ & $-0.749^{* *}$ & -0.381 & 0.464 & $-0.822^{* *}$ & 0.030 & $-0.815^{* *}$ & 0.033 & 0.47 & $0.648^{*}$ \\
\hline
\end{tabular}

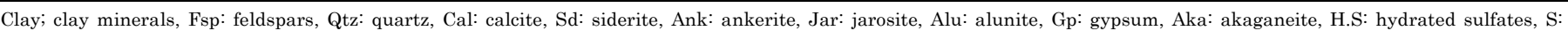
sulfides, Hem: hematite.

${ }^{*} p<0.05$.

** $p<0.001$ 
Table 5

Factors derived by PCA of major elements and mineralogical composition of mine waste materials.

\begin{tabular}{lll}
\hline Factor & Variables & Total variance $(\%)$ \\
\hline $\mathrm{F} 1$ & $\begin{array}{l}\text { - } \mathrm{Al}_{2} \mathrm{O}_{3} ;-\mathrm{SiO}_{2} ;-\mathrm{K}_{2} \mathrm{O} ;-\mathrm{TiO}_{2} ;+\mathrm{Fe}_{2} \mathrm{O}_{3} ; \\
\quad \text {-clay minerals; +hydrated sulfates; }\end{array}$ & 36.2 \\
& +sulfides; +hematite \\
F2 & - $\mathrm{MgO} ;$-CaO; - $\mathrm{MnO}_{2} ;$-calcite; & 27.2 \\
& -siderite; -ankerite \\
F3 & $+\mathrm{SO}_{3} ;$ +jarosite; +gypsum; -alunite & 9.9 \\
F4 & $-\mathrm{P}_{2} \mathrm{O}_{5} ;$-feldspars; -quartz \\
F5 & $-\mathrm{Na}_{2} \mathrm{O} ;$-Loss of ignition; +akaganeite & 6.3 \\
\hline
\end{tabular}

those from river beds subject to flash-flood, and, therefore, susceptible to water transport, showed the highest percentage of coarse materials. Trace-element content was generally high, especially for $\mathrm{Pb}$ and $\mathrm{Zn}$, although there were also substantial As concentrations. This element is associated with sulfides in this type of deposit (as is also the case with $\mathrm{Cu}$ and $\mathrm{Cd}$ ).

The chemical composition of the samples highlights the alteration processes endured by these materials (Table 3). Fig. 4 shows the variability in major components in the altered samples. The $\mathrm{P}_{2} \mathrm{O}_{5}$ and $\mathrm{TiO}_{2}$ contents were homogeneous whereas the rest of the components varied with the degree of alteration. Taking into account the mean value (Table 3 ), the silica content was lower in fresh rocks than in the altered rocks (Table 1), suggesting a gradual loss of the essential rock components, particularly K-feldspars. The $\mathrm{MgO}, \mathrm{Al}_{2} \mathrm{O}_{3}, \mathrm{P}_{2} \mathrm{O}_{5}$ and $\mathrm{K}_{2} \mathrm{O}$ contents were also lower, probably as a consequence of alteration of K-feldspars and micas (Faure, 1998).

Altered samples had high concentrations of total S, $\mathrm{CaO}$, total $\mathrm{Fe}$ and metals, incorporated in the system as a result of secondary or hypogene alteration. The total $\mathrm{Fe}, \mathrm{CaO}, \mathrm{ZnO}$ and $\mathrm{PbO}$ concentrations were much higher in these samples than in the parent rock samples due to hydrothermal processes, whereas $\mathrm{Na}_{2} \mathrm{O}$ and $\mathrm{MnO}_{2}$ did not show pronounced increases. Loss on ignition results were higher for altered samples, due to the incorporation of $\mathrm{H}_{2} \mathrm{O}$ and $\mathrm{CO}_{2}$.

X-ray diffraction results suggest that these samples have a complex mineralogy, with alteration products from hydrothermal processes and from weathering processes. Minerals from the host rock, such as micas (represented here by muscovite), feldspars and quartz, were found in lower proportions than in parent rock (Fig. 5). Primary alteration minerals are represented by chlorite and kaolinite (designated as clay minerals in the legend), siderite,

ankerite, sulfides and hematite, whereas weathering products associated with secondary alteration include calcite, gypsum and various hydrated sulfates, such as gunningite in $\mathrm{SH} 4$, hexahydrate in T3 and boyleite in T4. The sulfates, jarosite and alunite, may be associated with hypogene or secondary alteration, although in most cases they probably had a weathering origin.

\subsection{Relationship between major elements and mineralogical composition}

A Pearson's correlation matrix was made with major element and mineralogical composition of the altered samples (Table 4). Magnesium showed high positive correlation with $\mathrm{CaO}$ and $\mathrm{MnO}_{2}$, and all three were well correlated with carbonated phases (calcite, siderite and ankerite). In addition, $\mathrm{MgO}$ was negatively correlated with jarosite. Aluminium, $\mathrm{SiO}_{2}, \mathrm{~K}_{2} \mathrm{O}$ and $\mathrm{TiO}_{2}$ were positively correlated among themselves and with clay minerals, but negatively with total $\mathrm{S}$ and total $\mathrm{Fe}$ content, other hydrated sulfates, sulfides and hematite. Total S was positively correlated with total $\mathrm{Fe}$, and both were positively correlated with jarosite and alunite and negatively correlated with $\mathrm{Al}_{2} \mathrm{O}_{3}, \mathrm{SiO}_{2}, \mathrm{~K}_{2} \mathrm{O}, \mathrm{TiO}_{2}$ and clay minerals. In addition, total $\mathrm{Fe}$ was positively correlated with akaganeite and negatively correlated with calcite and feldspars. The loss on ignition (LOI), reflecting volatile elements, was positively correlated with total $\mathrm{S}$ and $\mathrm{Fe}$, which was consistent with the
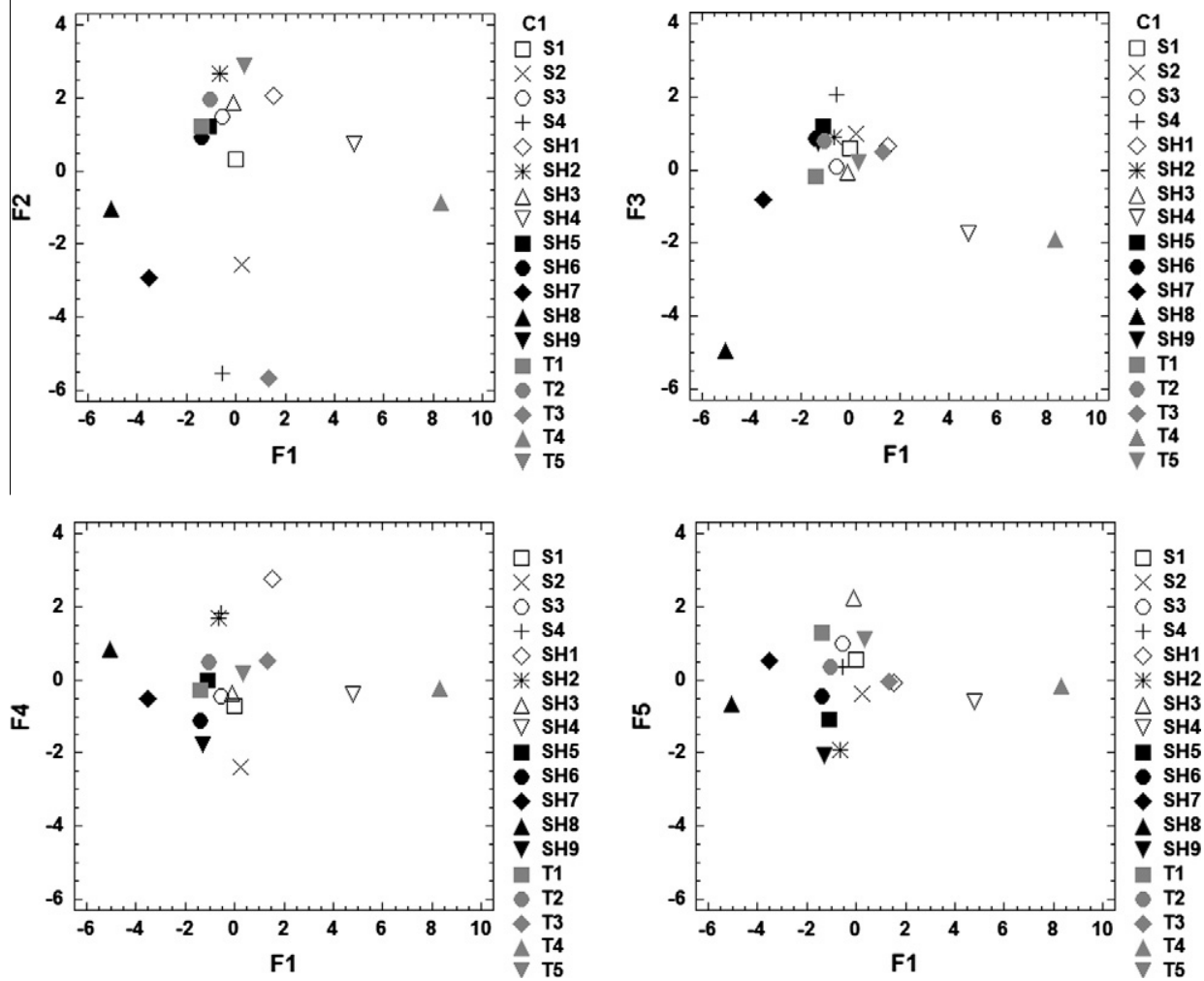

Fig. 6. Combined plot of scores and loadings obtained by PCA. Factor 1 vs. Factor 2 (7a) and Factor 1 vs. Factor 4 (7b). 
positive relationship obtained with hydrated sulfates, jarosites and hematite. The negative correlation with $\mathrm{Al}_{2} \mathrm{O}_{3}, \mathrm{SiO}_{2}, \mathrm{TiO}_{2}$, agrees with the negative correlation with clay minerals, which are rich in these components.

Principal components analysis (PCA) was carried and in this case, five factors explained $85 \%$ of the variance and showed eigenvalues above 1 (Table 5). Factor 1 distinguished between the Fe and $\mathrm{S}$ phases and the silicates; that is, those samples that contained hydrated sulfates, sulfides and hematite. Factor 2 was defined by the divalent carbonate phases on the negative part of the axis and $\mathrm{MgO}, \mathrm{CaO}$ and $\mathrm{MnO}_{2}$ in the positive part. Factor 3 separated samples containing alunite from those containing gypsum. Factor 3 also included total $\mathrm{S}$ and jarosite, being indicative of the degree of alteration suffered by the samples, because the presence of jarosite points to weathering processes.

Factor 4 includes feldspars and quartz, and Factor 5 includes akaganeite. Scores and loadings of F1, F2 and F3 in each sample are shown in Fig. 6. F1 and F2 separate materials containing hydrated sulfates, sulfides and hematite from those containing carbonated phases. The rest of the samples appeared in the quadrant that was positive for Factor 1 and negative for Factor 2, which indicated that they contained jarosite in their mineralogical composition. F1 and F3 showed that the most altered samples (with jarosite and gypsum) are located in the positive part of the $\mathrm{Y}$ axis.

\subsection{Geochemical behavior of the major elements}

Correlation coefficients of major oxides, $\mathrm{Al}_{2} \mathrm{O}_{3}, \mathrm{SiO}_{2}, \mathrm{TiO} 2, \mathrm{~K}_{2} \mathrm{O}$ and total $\mathrm{Fe}$, have been selected because they could be considered as immobile under alteration conditions (Yigit and Hofstra, 2003). Generally, correlation coefficients were not high (Table 4), meaning that these elements were not mobilised from these materials. The negative correlation between $\mathrm{Fe}$ and the other elements demonstrates that it did not originate from the rock, but instead was introduced by other processes, such as hydrothermal activity. In order to evaluate the geochemical behavior of other elements, Ti has been considered as the least mobile being exclusively bound to primary minerals, meaning that the composition of the phases containing Ti did not vary (Ortiz-González, 1991). Considering this methodology in the study area, the ratio between the $\mathrm{TiO}_{2}$ mean
Table 7

$\mathrm{SiO}_{2} / \mathrm{Al}_{2} \mathrm{O}_{3}$ and $\mathrm{Al}_{2} \mathrm{O}_{3} / \mathrm{Fe}_{2} \mathrm{O}_{3}$ ratios of mine waste materials (mass ratio).

\begin{tabular}{lll}
\hline Sample & $\mathrm{SiO}_{2} / \mathrm{Al}_{2} \mathrm{O}_{3}$ & $\mathrm{Al}_{2} \mathrm{O}_{3} / \mathrm{Fe}_{2} \mathrm{O}_{3}$ \\
\hline $\mathrm{SH} 1$ & 3.53 & 0.40 \\
$\mathrm{SH} 2$ & 1.84 & 1.32 \\
$\mathrm{SH} 3$ & 5.78 & 0.67 \\
$\mathrm{SH} 4$ & 3.84 & 0.39 \\
$\mathrm{SH} 5$ & 2.06 & 1.13 \\
$\mathrm{SH} 6$ & 2.64 & 1.08 \\
$\mathrm{SH} 7$ & 3.18 & 1.99 \\
$\mathrm{SH} 8$ & 3.22 & 2.47 \\
$\mathrm{SH} 9$ & 3.15 & 1.65 \\
$\mathrm{~T} 1$ & 3.78 & 0.81 \\
$\mathrm{~T} 2$ & 2.96 & 1.00 \\
$\mathrm{~T} 3$ & 3.73 & 0.75 \\
$\mathrm{~T} 4$ & 3.12 & 0.15 \\
$\mathrm{~T} 5$ & 2.89 & 0.80 \\
$\mathrm{~S} 1$ & 3.56 & 0.69 \\
$\mathrm{~S} 2$ & 3.39 & 0.63 \\
$\mathrm{~S} 3$ & 3.48 & 0.79 \\
S4 & 3.43 & 0.95 \\
Global & 3.16 & 0.84 \\
\hline
\end{tabular}

content in unaltered rocks divided by the $\mathrm{TiO}_{2}$ mean content in altered rocks was found to be 1.55 , and this constant was included in the analysis of the ratio host rock/altered rock for other elements, as follows:

Element ratio $1 / 4$ ðmean value in unaltered rocks=mean value in altered rocks) $\times 1: 55$

Values above unity indicate that the element has been solubilized, whereas values below unity suggested that the element has been introduced in the system (Fig. 7). In the samples, $\mathrm{Al}, \mathrm{Si}$, $\mathrm{Mg}, \mathrm{P}$ and $\mathrm{K}$ have undergone a partial solubilization process because the host rock/altered rock ratio was above unity; Mn showed the same tendency in almost all samples (Table 6, Fig. 7). Sulfur, Ca, $\mathrm{Fe}, \mathrm{Zn}, \mathrm{Pb}$ and $\mathrm{Na}$ concentrations are the consequence of alteration processes, with $\mathrm{S}$ showing the most homogeneous values. According to results of this study and taking into account published data from elsewhere, $\mathrm{Mg}, \mathrm{Al}, \mathrm{Si}, \mathrm{P}, \mathrm{K}$ and $\mathrm{Mn}$ were present as a result of solubilization processes, whereas the rest of the elements, $\mathrm{Na}, \mathrm{S}, \mathrm{Fe}$,
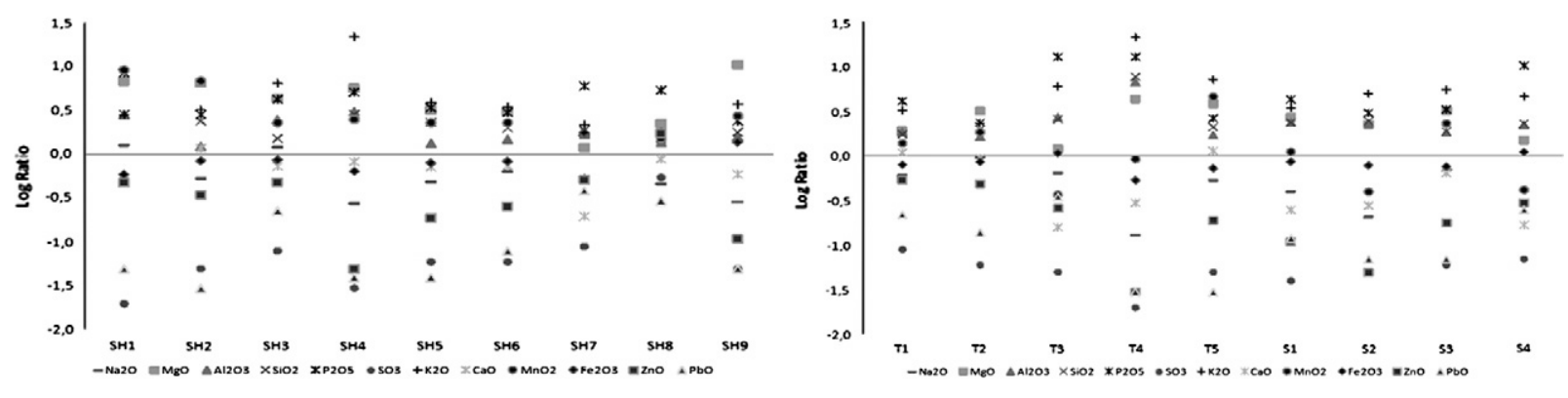

Fig. 7. Element ratio for major elements in mine waste materials.

Table 6

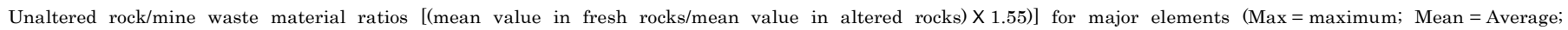
Min = minimum).

\begin{tabular}{|c|c|c|c|c|c|c|c|c|c|c|c|c|}
\hline & $\mathrm{Na}_{2} \mathrm{O}$ & $\mathrm{MgO}$ & $\mathrm{Al}_{2} \mathrm{O}_{3}$ & $\mathrm{SiO}_{2}$ & $\mathrm{P}_{2} \mathrm{O}_{5}$ & $\mathrm{SO}_{3}$ & $\mathrm{~K}_{2} \mathrm{O}$ & $\mathrm{CaO}$ & $\mathrm{MnO}_{2}$ & $\mathrm{Fe}_{2} \mathrm{O}_{3}$ & $\mathrm{ZnO}$ & $\mathrm{PbO}$ \\
\hline Maximum & 1.66 & 10.76 & 6.79 & 7.76 & 12.98 & 0.55 & 22.25 & 1.19 & 9.3 & 1.81 & 1.77 & 0.39 \\
\hline Mean & 0.65 & 3.82 & 2.28 & 2.49 & 5.43 & 0.08 & 6.06 & 0.64 & 2.45 & 0.96 & 0.35 & 0.14 \\
\hline Minimum & 0.13 & 1.21 & 1.25 & 1.54 & 2.36 & 0.02 & 1.61 & 0.16 & 0.37 & 0.54 & 0.03 & 0.03 \\
\hline GLOBAL & 0.45 & 2.72 & 2.02 & 2.17 & 4.06 & 0.05 & 3.83 & 0.41 & 1.11 & 0.86 & 0.15 & 0.06 \\
\hline
\end{tabular}


Table 8

Pearson's correlation matrix between mineralogical composition and metal contents of mine waste materials.

\begin{tabular}{|c|c|c|c|c|c|c|c|c|c|c|c|c|c|c|c|c|c|c|}
\hline & Clay & Fsp & Qtz & $\mathrm{Cal}$ & $\mathrm{Sd}$ & Ank & Jar & Alu & Gp & Aka & H.S. & S & Hem & $\mathrm{Pb}$ & $\mathrm{Cd}$ & $\mathrm{Zn}$ & $\mathrm{Cu}$ & As \\
\hline Fsp & 0.308 & & 0.038 & $0.520^{*}$ & 0.216 & 0.318 & -0.468 & 0.293 & 0.341 & $-0.487^{*}$ & 0.003 & 0.178 & -0.118 & -0.357 & -0.026 & -0.114 & $4-0.150$ & $0-0.113$ \\
\hline Qtz & 0.053 & 0.038 & & -0.278 & -0.418 & -0.316 & -0.024 & -0.080 & -0.094 & 0.151 & -0.338 & -0.425 & -0.242 & -0.087 & -0.151 & -0.042 & $2-0.113$ & $3-0.436$ \\
\hline Cal & 0.146 & $0.520^{*}$ & -0.278 & & $0.588^{*}$ & $0.685^{*}$ & $-0.702^{* *}$ & 0.354 & 0.374 & $-0.685^{* *}$ & 0.061 & 0.421 & -0.218 & -0.436 & -0.036 & -0.267 & $7-0.315$ & $5-0.228$ \\
\hline $\mathrm{Sd}$ & -0.029 & 0.216 & -0.418 & $0.588^{*}$ & & $0.795^{* *}$ & -0.018 & -0.085 & 0.341 & -0.392 & 0.333 & $0.566^{*}$ & -0.124 & -0.201 & 0.043 & -0.101 & $1-0.186$ & $5-0.088$ \\
\hline Ank & -0.096 & 0.318 & -0.316 & $0.685^{* *}$ & $0.795^{* *}$ & & 0.016 & -0.108 & $0.490^{*}$ & $-0.498^{*}$ & 0.173 & $0.727^{* *}$ & $* 0.158$ & -0.023 & 0.172 & -0.112 & $2-0.035$ & 0.060 \\
\hline Jar & -0.341 & -0.468 & $3-0.024$ & $4-0.702^{* * *}$ & -0.018 & 0.016 & & $-0.670^{* *}$ & -0.028 & 0.463 & 0.162 & 0.152 & 0.197 & $0.638^{* *}$ & 0.187 & 0.271 & 0.413 & 0.414 \\
\hline Alu & 0.263 & 0.293 & -0.080 & 0.354 & -0.085 & -0.108 & $-0.670^{* *}$ & & -0.326 & -0.270 & -0.108 & -0.150 & -0.086 & $-0.675^{* *}$ & * -0.058 & -0.170 & $0-0.378$ & $8-0.418$ \\
\hline $\mathrm{Gp}$ & 0.137 & 0.341 & -0.094 & 0.374 & 0.341 & $0.490^{*}$ & -0.028 & -0.326 & & $-0.711^{* *}$ & -0.217 & 0.177 & -0.340 & 0.172 & 0.002 & -0.140 & 0.179 & 0.336 \\
\hline Aka & -0.286 & $-0.487^{*}$ & * $\quad 0.151$ & $1-0.685^{* *}$ & -0.392 & $-0.498^{*}$ & 0.463 & -0.270 & $-0.711^{\ldots}$ & & 0.158 & 0.162 & 0.366 & 0.339 & 0.171 & $0.664^{* *}$ & 0.304 & 0.010 \\
\hline H.S. & $-0.624^{* * *}$ & 0.003 & -0.338 & 0.061 & 0.333 & 0.173 & 0.162 & -0.108 & -0.217 & 0.158 & & $0.706^{* *}$ & $0.812^{* * *}$ & 0.132 & 0.430 & $0.601^{*}$ & $* \quad-0.035$ & $5-0.018$ \\
\hline $\mathrm{S}$ & $-0.614^{* *}$ & 0.178 & -0.425 & 0.421 & $0.566^{*}$ & $0.727^{* *}$ & 0.152 & -0.150 & 0.177 & -0.162 & $0.706^{* *}$ & & $0.562^{*}$ & 0.117 & $0.472^{*}$ & 0.323 & -0.010 & 0.090 \\
\hline Hem & $\mathrm{n}-0.747^{* *}$ & -0.118 & -0.242 & -0.218 & -0.124 & -0.158 & 0.197 & -0.086 & -0.340 & 0.366 & $0.812^{\pi n}$ & $0.562^{*}$ & & 0.188 & $0.470^{*}$ & $0.595^{*}$ & 0.025 & 0.048 \\
\hline $\mathrm{Pb}$ & -0.153 & -0.357 & -0.087 & $7-0.436$ & -0.201 & -0.023 & $0.638^{*}$ & $-0.675^{* *}$ & 0.172 & 0.339 & 0.132 & 0.117 & 0.188 & & 0.384 & $0.499^{*}$ & $0.842^{* *}$ & $0.565^{*}$ \\
\hline $\mathrm{Cd}$ & -0.269 & -0.026 & -0.151 & -0.036 & 0.043 & 0.172 & 0.187 & -0.058 & 0.002 & 0.171 & 0.430 & $0.472^{*}$ & $0.470^{*}$ & 0.384 & & $0.866^{* *}$ & * 0.441 & 0.391 \\
\hline $\mathrm{Zn}$ & -0.336 & -0.114 & $=-0.042$ & -0.267 & -0.101 & -0.112 & 0.271 & -0.170 & -0.140 & $0.664^{* *}$ & $0.601^{* *}$ & 0.323 & $0.595^{*}$ & $0.499^{*}$ & $0.866^{* *}$ & & $0.526^{*}$ & 0.307 \\
\hline $\mathrm{Cu}$ & 0.097 & -0.150 & -0.113 & -0.315 & -0.186 & -0.035 & 0.413 & -0.378 & 0.179 & 0.304 & -0.035 & -0.010 & 0.025 & $0.842 \cdots$ & 0.441 & 0.526 & & 0.437 \\
\hline As & 0.068 & -0.113 & -0.436 & -0.228 & -0.088 & 0.060 & 0.414 & -0.418 & 0.336 & 0.010 & -0.018 & 0.090 & 0.048 & $0.565^{\pi}$ & 0.391 & 0.307 & 0.437 & \\
\hline
\end{tabular}

Clay: clay minerals, Fsp: feldspars, Qtz: quartz, Cal: calcite, Sd: siderite, Ank: ankerite, Jar: jarosite, Alu: alunite, Gp: gypsum, Aka: akaganeite, H.S: hydrated sulfates, S: sulfides, Hem: hematite.

* $p<0.05$.

*** $p<0.001$.

Table 9

Factors derived by PCA of mineralogical composition and trace elements in mine waste materials.

\begin{tabular}{lll}
\hline Factor & Variables & $\begin{array}{l}\text { Total variance } \\
(\%)\end{array}$ \\
\hline F1 & +calcite; -akaganeite; -Pb & 28.7 \\
F2 & $\quad$ +quartz; -siderite; -ankerite; -sulfides & 22.8 \\
F3 & $\quad+$ gypsum; -other hydrated sulfates; -hematite; & 15.7 \\
& +Cu; +As & \\
F4 & +clay minerals; +feldspars; -jarosite; +alunite; & 9.1 \\
& + Cd; +Zn & \\
\hline
\end{tabular}

$\mathrm{Zn}$ and $\mathrm{Pb}$ have been introduced into the system. This behavior suggests that the hydrothermal fluids were enriched in $\mathrm{S}, \mathrm{Fe}, \mathrm{Zn}$ and $\mathrm{Pb}$, the resulting sulfides were subsequently weathered (Navarro-Hervás, 2004).

Other ratios allow alteration processes to be identified, such as the $\mathrm{SiO}_{2} / \mathrm{Al}_{2} \mathrm{O}_{3}$ and $\mathrm{Al}_{2} \mathrm{O}_{3} / \mathrm{Fe}_{2} \mathrm{O}_{3}$ ratios (Yigit and Hofstra, 2003). The $\mathrm{SiO}_{2} / \mathrm{Al}_{2} \mathrm{O}_{3}$ ratio in altered rocks was similar in all samples, reflecting their acidic nature. The global value (3.16) indicates a significant degree of alumina solubilization, suggesting that the hydrothermal fluids had low $\mathrm{pH}$. On the other hand, $\mathrm{Al}_{2} \mathrm{O}_{3} / \mathrm{Fe}_{2} \mathrm{O}_{3}$
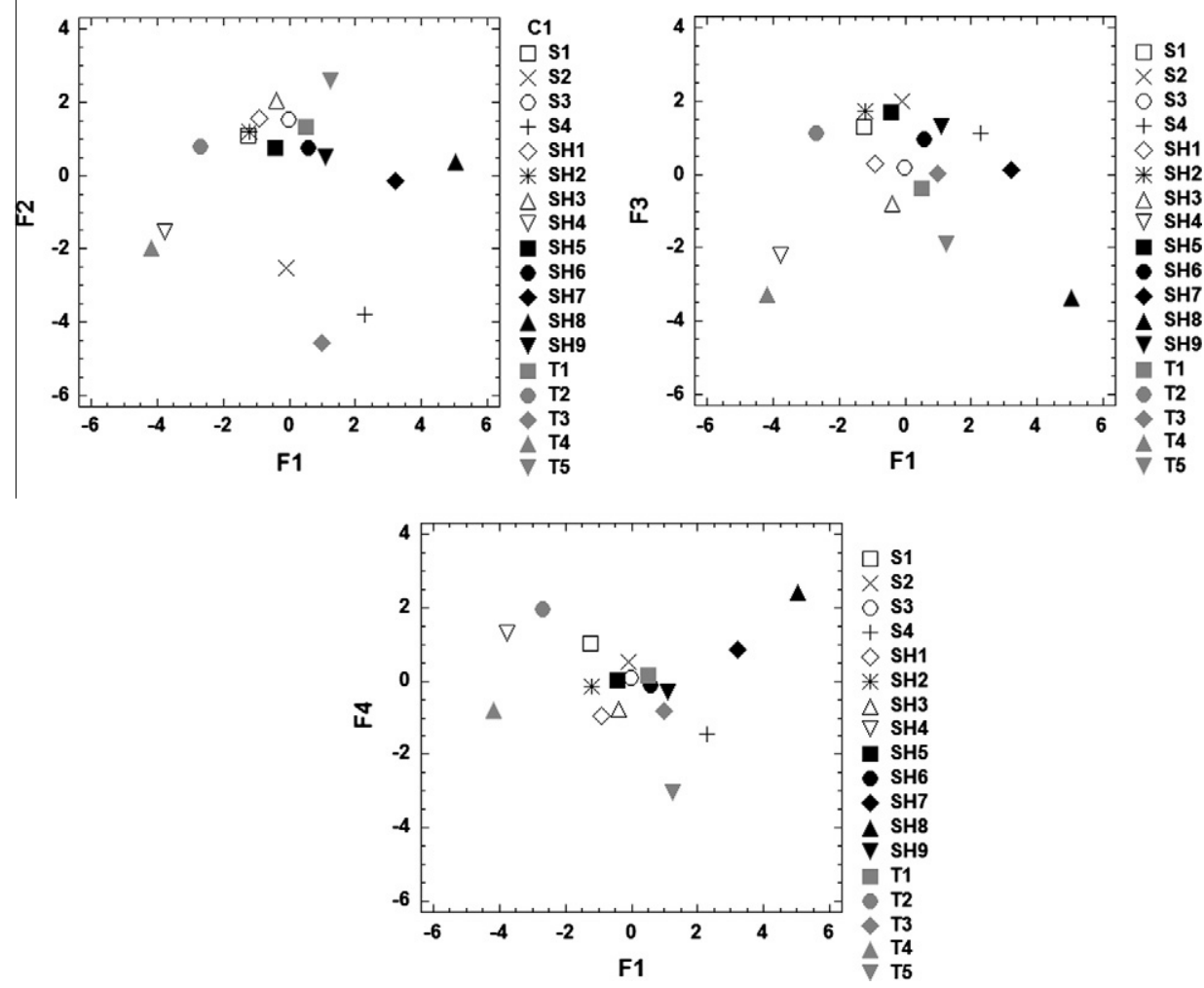

Fig. 8. Combined plot of scores and loadings obtained by PCA. Factor 1 vs. Factor 2 (9a) and Factor 1 vs. Factor 3 (9b). 
ratios below 1 suggest a $\mathrm{Fe}$ enrichment and a parallel loss of $\mathrm{Al}$ during the alteration process (Table 7).

\subsection{Relationship between total trace element content and mineralogical composition}

Results of correlation analysis between mineralogical composition and trace element content are shown in Table 8 and two mineral groups are identified. Minerals from the host rock, like clays, feldspars or quartz, were not correlated among themselves and not with the total metal contents. Host materials affected to a greater degree by volcanism and/or hydrothermal processes could also contain jarosite and alunite. On the other hand, jarosite, together with akaganeite, calcite, gypsum and other hydrated sulfates are minerals typically found associated with weathering processes, and were correlated with total trace element content. In addition, alunite was positively correlated with jarosite, and gypsum with akaganeite, confirming the co-genetic relationship of these minerals. Some minerals could be present in both groups, such as hematite, calcite, gypsum and clay minerals. In addition, correlation results showed the existence of a positive correlation between $\mathrm{Fe}$ phases, like sulfides (mainly pyrite), siderite, ankerite and hydrated sulfates (Table 8).

For the principal component analysis, four factors were chosen, explaining $77 \%$ of the variance and showing eigenvalues above 1 (Table 9). Factor 1 placed calcite (primary and secondary) in the positive part of the axis, and akaganeite, formed by weathering processes, in the negative part. Lead indicates the maximum degree of hypogene mineralization and also appears in the negative part of the axis, together with akaganeite (maximum alteration). Factor 2 was defined by $\mathrm{Fe}$ minerals, such as siderite, ankerite and sulfides (mainly pyrite) in the negative part of the axis, and quartz in the positive part. Factor 3 includes a negative correlation between gypsum, indicating different origins. This factor also includes other hydrated sulfates, in the negative direction and $\mathrm{Cu}$ and As in the positive direction. The difference in sign of the correlation coefficients of gypsum and other hydrated sulfates could be explained by taking into account that secondary gypsum is formed when acid waters are neutralized by carbonate-rich materials whereas efflorescences of other hydrated sulfates were formed when carbonate materials were not present. Finally, factor 4 includes materials from host rock affected to a greater degree by volcanism and/or hydrothermal processes, because this factor includes jarosite and alunite together with feldspars and $\mathrm{Cd}$ and $\mathrm{Zn}$, which are associated with host rock with alunite. The values and loadings obtained for F1, F2 and F3 in each sample are shown in Fig. 8.

\section{Conclusions}

Hydrothermal mineralization in the study area acted on the host rocks to deposit metal sulfides and quartz in conjunction with iron carbonates (siderite and ankerite). Surficial materials in the study area, including host rock and mine waste, have experienced a weathering process, which has generating supergene products, including $\mathrm{Fe}$ and $\mathrm{Mn}$ oxides and hydroxides, carbonates, hydrated sulfates and jarosites. The geochemical behavior of the main components in the alteration process indicated a loss of $\mathrm{Na}, \mathrm{S}, \mathrm{Ca}, \mathrm{Fe}$ and metals, whereas others, including $\mathrm{Mg}, \mathrm{Al}, \mathrm{Si}, \mathrm{P}, \mathrm{K}$ and $\mathrm{Mn}$ were added.
Weathering has affected both primary and secondary mineralization. The oxidation of sulfides due to the instability of these phases in an oxic acidic medium was the main reason for the increased acidity and for the formation of products in the deposits from mining activities. Final stages of these processes have led to the production of a large number of sulfates with different degrees of hydration and which appear as saline deposits, sometimes retaining trace elements released during the oxidation process.

The gypsum may have resulted from the alteration of plagioclase and its carbonation or from the neutralization of the $\mathrm{SO}_{4}$-rich waters after alteration of the sulfides. Calcite is the result of the carbonation of plagioclase in the absence of acid drainage. Acid waters, produced in mining areas, may react with precipitated carbonates, neutralizing the $\mathrm{pH}$, being a first step in the natural attenuation of trace element contamination.

\section{Acknowledgment}

The authors are grateful to the Spanish Ministerio de Ciencia e Innovación (CTM2008-04567).

\section{References}

Amonette, J.E., Sanders, R.W., 1994. Nondestructive techniques for bulk elemental analysis. In: Amonette, J.E., Zelazny, L.W. (Eds.), Quantitative Methods in Soil Mineralogy. Soil Science Society of America, Madison, Wisconsin, pp. 1-48.

Bhattacharya, A., Routh, J., Jacks, G., Bhattacharya, P., Mörth, M., 2006. Environmental assessment of abandoned mine tailings in Adak, Västerbotten district (northern Sweden). Appl. Geochem. 21, 1760-1780.

Faure, G., 1998. Principles and Applications of Geochemistry. Prentice-Hall, New Yersey.

López Ruíz, J., Cebriá, J.M., Doblas, M., 2002. Cenozoic volcanism I: the Iberian Peninsula. In: Gibbons, W., Moreno, M.T. (Eds.), The Geology of Spain. Geological Society, London, pp. 417-438.

Lottermoser, B.G., 2007. Mine Wastes: Characterization, Treatment and Environmental Impacts. Springer, Berlin.

Manteca, J.I., Ovejero, G., 1992. Los yacimientos de $\mathrm{Zn}, \mathrm{Pb}, \mathrm{Ag}-\mathrm{Fe}$ del distrito minero La Unión-Cartagena. In: García Guinea, J., Martínez Frías, J. (Eds.), Recursos Minerales de España, Consejo Superior de Investigaciones Científicas, Madrid, pp. 1085-1102.

Martínez-Sánchez, M.J., Navarro, M.C., Pérez-Sirvent, C., Marimón, J., Vidal, J., García-Lorenzo, M.L., Bech, J., 2008. Assessment of the mobility of metals in a mining-impacted coastal area (Spain, Western Mediterranean). J. Geochem. Explor. 96, 171-182.

Navarro-Hervás, M.C., 2004. Movilidad y biodisponibilidad de metals pesados en el emplazamiento minero Cabezo Rajao (Murcia). Ph.D. Thesis, Univ. Murcia, Murcia, Spain.

Navarro, M.C., Pérez-Sirvent, C., Martínez-Sánchez, M.J., Vidal, J., Marimón, J., 2006 Lead, cadmium and arsenic bioavailability in the abandoned mine site of Cabezo Rajao (Murcia, SE Spain). Chemosphere 63, 484-489.

Navarro, M.C., Pérez-Sirvent, C., Martínez-Sánchez, M.J., Vidal, J., Tovar, P.J., Bech, J., 2008. Abandoned mine sites as a source of contamination by heavy metals: a case study in a semi-arid zone. J. Geochem. Explor. 96, 183-193.

Ortiz-González, R., 1991. Quimismo de los productos de alteración supergénica en el distrito minero de Mazarrón (Murcia). Ph.D. Thesis, Univ. Murcia, Murcia, Spain.

Pawlowsky-Glahn, V., Egozcuel, J.J., 2006. Compositional Data and Their Analysis: An Introduction. Geological Society, London, pp. 1-10, Special Publication 264

Piatak, N.M., Seal II, R.R., Hammarstrom, J.M., 2004. Mineralogical and geochemical controls on the release of trace elements from slag produced by base- and precious-metal smelting at abandoned mine sites. Appl. Geochem. 19, 10391064 .

Robles-Arenas, V.M., Rodríguez, R., García, C., Manteca, J.I., Candela, L., 2006. Sulfidemining impacts in the physical environment: Sierra de Cartagena-La Unión (SE Spain) case study. Environ. Geol. 51, 47-64.

Rodríguez, L., Ruiz, E., Alonso-Azcárate, J., Rincón, J., 2009. Heavy metal distribution and chemical speciation in tailings and soils around a $\mathrm{Pb}-\mathrm{Zn}$ mine in Spain. J. Environ. Manage. 90, 1106-1116.

Rösler, H.J., Lange, H., 1972. Geochemical Tables. Elsevier, New York.

Ure, A.M., 1995. Methods of analysis for heavy metals in soils. In: Alloway, B.J. (Ed.), Heavy Metals in Soils. Blackie, London, pp. 58-102.

Yigit, O., Hofstra, A.F., 2003. Lithogeochemistry of Carlin-type gold mineralization in the Gold Bar district, Battle Mountain-Eureka trend, Nevada. Ore. Geol. Rev. 22, 201-224. 